\title{
OPTIMALISASI PERAN ADVOKAT DALAM PENEGAKAN HUKUM EKONOMI SYARIAH DI WILAYAH PENGADILAN TINGGI AGAMA SURABAYA
}

\author{
Zulkifli Hidayatullah \\ Universitas Muhammadiyah Surabaya \\ E-mail: zulkiflihidayatube@gmail.com
}

\begin{abstract}
Abstrak
Gugatan perkara-perkara ekonomi syariah khususnya yang diajukan oleh para advokat di Pengadilan Agama dalam wilayah Pengadilan Tinggi Agama Surabaya, faktanya banyak dijumpai berakhir dengan putusan NO (niet on vankelijke verklaard) ada banyak faktor yang menjadi pertimbangan hakim dalam putusan tersebut, diantaranya adalah kekaburan gugatan (obscuur libel) yang dibuat oleh para advokat, baik terkait dengan akad dan tempat penyelesaian perkara.

Penelitian ini bertujuan untuk mengetahui peran advokat dalam proses penegakan hukum ekonomi syariah di Pengadilan Agama dalam wilayah Pengadilan Tinggi Agama Surabaya untuk mencapai kebenaran dan keadilan;untuk mengetahui faktor-faktor yang mempengaruhi rendahnya peran advokat dalam penegakan hukum ekonomi syariah di Pengadilan Agama dalam wilayah Pengadilan Tinggi Agama Surabaya; dan untuk merumuskan konsep materi yang tepat tentang standarisasi kurikulum pendidikan khusus profesi advokat tentang pemahaman dan pengetahuan hukum ekonomi syariah oleh advokat.

Penelitian ini menggunakan diskriptif kualititatif dengan perpaduan pendekatan teknik fenomenologis. Peneliti akan mengkaji lebih dalam suatu fenomena yang sedang terjadi pada suatu lembaga perhimpunan Advokat dengan metode survey.

Dari analisis tentang optimalisasi peran Advokat di DPC PERADI Surabaya, penanganan sengketa ekonomi syari'ah merupakan tugas dan tantangan baru yang harus dihadapi oleh Advokat di lingkungan peradilan dalam Wilayah Hukum Pengadilan Tinggi Agama Surabaya.

Hasil penelitian ini menunjukkan beberapa temuan yaitu peran Advokat dapat optimal apabila mengerti dan memahami pokok perkara yang akan dibelanya, dan Advokat dapat mengakomodir kepentingan hukum kliennya. Formula untuk meningkatkan optimalnya peran advokat dalam penegakan hukum ekonomi syariah di Pengadilan Agama dalam Wilayah Pengadilan Tinggi Agama Surabaya adalah (a) adanya sertifikasi pengetahuan khusus ilmu ekonomi syariah; (b) diperlukan suatu model pembekalan yang tepat untuk menguatkan kualitas profesionalisme para calon Advokat.
\end{abstract}

Kata Kunci : Peran Advokat, Penegakan Hukum Ekonomi Syariah. 


\section{PENDAHULUAN}

Profesionalisme advokat bukan diukur oleh keahliannya beretorika atau upaya-upaya yang tidak dibenarkan oleh hukum untuk dapat mempengaruhi putusan hakim, tetapi bagaimana advokat dapat membantu kliennya secara realistis dan objektif dengan berargumentasi hukum yang baik di depan pengadilan. Advokat Indonesia harus segera merevitalisasi

1 Advokat tidak hanya berperan sebagai pendamping dalam setiap proses hukum (litigasi), tetapi lebih dari itu, yaitu menjadikan masyarakat mengerti akan hukum dan dapat mengkritisi produk hukum yang ada, yaitu dengan memberikan pendidikan hukum dan kewarganegaraan bagi masyarakat (civic education). ${ }^{2}$ Advokat dapat memberikan pencerahan hukum bagi masyarakat agar mereka tidak buta dan gagap terhadap hukum. Pemberdayaan masyarakat (empowering society) dalam peran serta penegakan hukum dirasa sangat penting, karena supremasi hukum tidak hanya dibangun oleh elit saja, tetapi juga oleh masyarakat. $^{3}$

11 Frans Hendra Winarta, Pembahasan RUU Advokat dan Agenda Perbaikan Profesi Advokat, Makalah Seminar, 27 Februari, 2003, hlm. 5 .

${ }^{2}$ Binziad Kadafi dkk., Advokat Indonesia Mencari Legitimasi : Studi Tentang Tanggung Jawab Profesi Hukum di Indonesia, PSHK, Jakarta, 2001, hlm. 182.

${ }^{3}$ Muhadi Zainuddin, Peran Sosialisasi UU Advokat dalam Pemberdayaan Kesadaran Hukum Masyarakat, Jurnal Al-Mawarid Edisi XII Tahun 2004, hlm. 91. peran dan fungsinya. Sudah saatnya orientasi profesi advokat dikembalikan kepada kepentingan publik yaitu membela masyarakat kecil harus menjadi agenda utama para advokat sebagai individu dan komunitasnya secara kolektif, bukan sekedar sebagai pekerjaan sambilan (vocation) tetapi profesi yang memikul tanggung jawab mewujudkan kesadaran dan budaya hukum yang baik bagi masyarakat. Profesi Advokat sebagai Officium Nobile (profesi yang terhormat) sangat ditentukan oleh tingkat intelektual dan integritas seorang Advokat. Tanggung jawab Advokat untuk mengakomodir kepentingan hukum kliennya. Pemahaman Advokat baik dalam substansi gugatan maupun pemahaman tentang ilmu ekonomi syariah yang memiliki kekhususan harus ditingkatkan agar dapat memenuhi dan mengakomodir kepentingan kliennya. Sedangkan tingkat integritas berhubungan dengan moralitas seorang Advokat yang harus mengedepankan kepentingan publik diatas kepentingan golongan.

Berdasarkan hal tersebut, maka Peneliti berusaha mengkaji sejauh mana efektifitas peran advokat dalam penegakan hukum ekonomi syariah di Pengadilan Agama dalam wilayah Pengadilan Tinggi Agama Surabaya setelah berlakunya Undang-Undang Nomor 3 Tahun 2006 dengan harapan tulisan ini dapat berkontribusi untuk 
memberikan solusi bagi upaya peningkatan peran advokat secara maksimal. Ketidakpahaman para advokat mengenai hukum ekonomi syariah yang berlaku di peradilan agama tentunya dapat merugikan para pihak (kliennya) sehingga diperlukan suatu rumusan pemikiran agar peran advokat dalam penegakan hukum ekonomi syariah di pengadilan agama dapat optimal. Hal inilah yang akan menjadi pokok kajian peneliti yaitu optimalisasi peran advokat dalam penegakan hukum ekonomi syariah di pengadilan agama.

\section{METODE ANALISIS DATA}

Penelitian ini bermaksud untuk mendeskripsikan secara penuh tentang pengalaman dan mengemukan persepsi peneliti terhadap suatu pengalaman atau fenomena yang terjadi. Oleh karena itu, peniliti dalam melakukan penelitian ini menggunakan pendekatan fenomenologi. Persepsi peneliti dalam penelitian ini berdasarkan pada teoriteori yang berkaitan dengan fenomena tersebut.

Dalam penelitian ini peneliti akan menggambarkan secara penuh bagaimana sistem pemdampingan Advokat kepada klien kurang maksimal yang terjadi pada wilayah hokum Pengadilan Tinggi Agama Surabaya. Kemudian dianalisis berdasarkan teori keadilan, teori advokat, dan teori peradilan. Untuk mencapai tujuan tersebut, peneliti menggunakan metode deskriptif dengan pendekatan kualitatif.

\begin{abstract}
Penelitian deskriptif adalah penelitian yang bertujuan untuk membuat deskripsi atau gambaran mengenai fakta-fakta, sifat-sifat, serta hubungan antara fenomena yang diselidiki lalu dianalisis ${ }^{4}$
\end{abstract}

Sedangkan penelitian kualitatif merupakan penelitian yang bersifat deskriptif karena bertujuan untuk menganalisis secara mendalam tentang sesuatu menggunakan teori-teori yang berkaitan dengan fakta-fakta atau fenomena yang sedang diteliti. Dalam penelitian ini, perspektif subjek lebih ditonjolkan sehingga hasil dalam penelitian ini berupa suatu teori, bukan berupa penolakan atau penerimaan terhadap teori yang digunakan seperti dalam penelitian kuantitatif. ${ }^{5}$

Peneliti akan memaparkan tentang fakta-fakta yang berkaitan dengan hasil putusan Pengadilan Agama tingkat satu pada wilayah hokum Pengadilan Tinggi Agama Surabaya dengan cara mengumpulkan data selengkap-lengkapnya tentang objek kajian yang dimaksud. Kemudian data tersebut dianalisis menggunakan teoriteori dan aturan-aturan yang berkaitan dengan upah guna menemukan konsep yang ideal menurut hukum Islam dalam pemberian upah.

4 Saifudin Azwar, Metode Penelitian, (Yogyakarta: Pustaka Pelajar Offset, 1998), 128.

${ }^{5}$ Wikipedia, Penelitian Kualitatif. 3 November 2016. http://id.wikipedia.org diakses pada 20 April 2017. 
Jenis penelitian yang digunakan dalam penelitian ini adalah penelitian lapangan (field research). Penelitian lapangan bertujuan mempelajari secara intensif tentang latar belakang keadaan sekarang dan interaksi suatu sosial, individu, kelompok, lembaga, dan masyarakat. ${ }^{6}$ Penelitian lapangan pada penelitian ini dilakukan di DPC PERADI Jalan Tunjungan No. 76 Surabaya.

\section{KAJIAN PUSTAKA}

\section{Eksistensi Advokat, Latar Belakang dan Profesionalisme}

\section{Keberadaan dan Keterlibatan} Advokat dalam Proses Pengajuan Gugatan

Advokat sebagai salah satu pilar penegakan supremasi hukum dan hak asasi manusia merupakan salah satu unsur sistem peradilan. Advokat memiliki peran, tugas dan fungsi yang demikian luas dalam memberikan jasa profesional mereka kepada masyarakat. Advokat adalah orang yang berprofesi memberi jasa hukum, baik di dalam maupun di luar pengadilan yang memenuhi persyaratan berdasarkan UndangUndang RI Nomor 18 Tahun 2003 tentang Advokat. Jasa hukum yang diberikan Advokat berupa konsultasi hukum, bantuan hukum,

\footnotetext{
${ }^{6}$ Husaini Usman dan Purnomo Setiady Akbar, Metodologi Penelitian Sosial, (Jakarta: Bumi Aksara, 2004), 5.
}

menjalankan kuasa, mewakili, mendampingi, membela, dan melakukan tindakan hukum lain untuk kepentingan hukum klien baik orang, badan hukum, atau lembaga lain yang menerima jasa hukum dari Advokat. ${ }^{7}$

Peran Advokat dalam hukumAdvokat disebut juga penasihat hukum adalah orang yang diberi kuasa untuk memberi bantuan di bidang hukum baik perdata atau pidana kepada yang memerlukannya, baik berupa nasehat (konsultasi) maupun bantuan hukum aktif baik di dalam maupun di luar pengadilan dengan jalan mewakili, mendampingi, membela dan melakukan tindakan hukum lain untuk kepentigan hukum para pengguna jasanya. ${ }^{8}$

Keberadaan dan keterlibatan Advokat dalam proses pengajuan gugatan khususnya dalam penanganan perkara ekonomi syariah di pengadilan agama adalah meneliti dan mengkaji masalah untuk selanjutnya melakukan penetapan hukum yang akan dituangkan dalam gugatannya. Setelah memperoleh surat kuasa maka Advokat berkewajiban

7 Welin Kusuma, Profesi Advokat, http://welinkusuma.blogspot.com, Diakses pada Tanggal 15 Mei 2006.

8 Muhammad Ridwan, Peran Advokat Dalam Hukum, http://coretanberkelas.blogspot.com, Diakses pada Tanggal 2 November 2014. 
membuat surat gugatan dalam hal ini dibuat secara tertulis karena pada dasarnya gugatan secara langsung hanya dapat diajukan oleh yang berkepentingan secara langsung. ${ }^{9}$

Konsep surat gugatan tertulis yang dalam hal ini dibuat oleh Advokat harus memuat identitas para pihak, alasan-alasan gugatan (fundamentum petendi atau posita), tuntutan (onderwerp van den eis met een duidelijke ed bepaalde conclusie)atau petitumserta tuntutan subsider atau pengganti. Jika salah satu unsur saja tidak dipenuhi dan tertuang dalam gugatan maka gugatan dapat dinyatakan obscuur libel (gugatan mengandung cacat hukum). Hal ini yang terjadi dalam perkara ekonomi syariah dalam 4 (empat) uraian perkara yang telah diuraikan diatas. Hakim menolak perkara tersebut (NO/gugatan tidak dapat diterima).

Keberadaan dan keterlibatan advokat dalam proses pengajuan gugatanyang paling penting menurut Peneliti adalah Substansi Hukum dalam gugatan tertulis.

\footnotetext{
${ }^{9}$ Ketentuan ini Sejalan dengan Keputusan Kasasi Mahkamah Agung Republik Indonesia Nomor : 369/K/SIP/1973 tanggal 4 Desember 1975 yang Menyatakan Bahwa Menurut Pasal 144 Ayat (10) RBg dan Pasal 120 HIR. Orang yang Diberikan Kuasa tidak Mempunyai Hak untuk Mengajukan Gugatan secara Lisan kepada Pengadilan. Lihat pula Murti Arto, Praktek Perkara Perdata pada Pengadilan Agama, Pustaka Pelajar, Yogyakarta, 1978, hlm. 40.
}

Subtansi hukum inilah yang akan dijadikan pembelaan hukum terhadap klien untuk mendapatkan hak-haknya. Apabila seorang Advokat tidak tepat/salah dalam mencantumkan substansi hukum dalam gugatan maka kepentingan hukum klien tentunya sulit untuk didapatkan.

2. Latar Belakang Pendidikan dan Pengalaman Advokat dalam Menangani Perkara Ekonomi Syariah di Pengadilan Agama

Advokat yang berlatar belakang pendidikan hukum adalah seorang yang memiliki pengetahuan yang baik. Latar belakangnya sebagai seorang sarjana hukum tentunya telah belajar bagaimana melakukan penerapan hukum untuk membela hak-hak kliennya. Hal inilah yang dijadikan bekal seorang Advokat untuk mendampingi kliennya.

Latar belakang pendidikan hukum Advokat hanyalah sebatas pengetahuan umum saja. Apabila seorang Advokat berlatar belakang sebagai seorang sarjana hukum maka yang diperolehnya selama "mengenyam bangku kuliah" adalah hanya sebatas mata kuliah hukum acara peradilan agama. Para Advokat yang berlatar belakang sarjana hukum tersebut hanya sebatas mengetahui dokmatika hukum bahwa di peradilan agama menggunakan Undang-Undang Peradilan Agama sebagai dasar 
hukumnya dan HIR dan RBg sebagai dasar hukum acara yang diadikan acuan di peradilan agama. Sedangkan pengetahuan tentang hukum waris belumlah secara eksplisit diajarkan pada jenjang kuliah strata-1.

Selanjunya untuk pengalaman seorang Advokat dalam menangani perkara ekonomi syariah di pengadilan agama adalah berdasarkan konsep dan pengalaman yang diperoleh saat melakukan magang sebelum menjadi seorang Advokat yang diizinkan melakukan beracara hukum di pengadilan agama. Seorang Advokat junior tentu akan bertanya terlebih dahulu kepada seniornya bagaimana menangani sebuah perkara ekonomi syariah. Seorang Advokat senior yang pernah menangani perkara ekonomi syariah akan menjelaskan pengalamannya dalam menangani perkara ekonomi syariah. Hal inilah yang menjadi dasar bagi seorang Advokat junior untuk menangani perkara ekonomi syariah di pengadilan agama. Namun hal ini menurut peneliti belumlah cukup sebelum Advokat tersebut mendapatkan pelatihan khusus ataupun bersertifikat hukum ekonomi syariah yang digunakan dalam praktek beracara di pengadilan agama.
3. Pemahaman dan Pengetahuan Advokat tentang Konsep-Konsep dan Teori Hukum Ekonomi Syariah

Pemahaman dan pengetahuan Advokat tentang konsep-konsep dan teori hukum ekonomi syariah tentu belumlah cukup tanpa mempelajarinya. Seorang Advokat dituntut untuk menggali dan melakukan penelusuran hukum terkait dengan pengetahuan hukum ekonomi syariah itu sendiri. Seorang Advokat yang tidak mendapatkan konsep dan teori hukum ekonomi syariah dengan detail saat kuliah tentu akan menghadapi kesulitan saat harus menentukan substansi hukum ekonomi syariah yang tepat saat melakukan pendampingan terhadap klien.

Konsep dan teori hukum ekonomi syariah yang rumit dan kompleks tentu harus didalami dengan sungguh-sungguh dan memerlukan waktu untuk dipahami. Hal ini tentu menjadi sebuah tantangan bagi para Advokat yang kelak akan menangani perkara ekonomi syariah. Apabila seorang Advokat berhasil memahami dan melakukan kajian tentang hukum ekonomi syariah maka Advokat tersebut layak untuk mendapampingi klien yang ingin memperoleh keadilan dari penegakan hukum ekonomi syariah 
di pengadilan agama. Namun apabila seorang Advokat belum memahami tentang konsep dan teori ekonomi syariah dengan baik maka hak-hak para klien tentu akan terabaikan.

Peran Advokat Dalam Penegakan Hukum Ekonomi Syariah di Pengadilan Agama

\section{Ilmu Ekonomi Syariah} Merupakan Pengatahuan Khusus bagi Advokat

Ilmu ekonomi syariah merupakan pengetahuan khusus bagi advokat. Profesi Advokat mempunyai arti sebagai bidang pekerjaan yang dilandasi pendidikan keahlian (keterampilan, kejuruan, dan sebagainya). Pengertian lain profesi Advokat adalah suatu pekerjaan pelayanan mengenai penerapan pengetahuan secara sistematis untuk mengatasi persoalan-persoalan ke dalam wawasan sebagai nilai-nilai utama yang mempunyai relevansi tinggi dalam masyarakat. ${ }^{10}$

Diperlukan kriteria dalam profesi Advokat yang diantaranya adalah pengetahuan, keahian kemahiran, pengabdiankepada kepentingan orang banyak, tidak mengutamakan keuntungan materi, adanya organisasi atau asosiasi profesi Advokat, pengakuan

10 Abdullah TW., Kode Etik Advokat Indonesia : Advokat Sebagai Profesi, https://advosolo.wordpress.com, Diakses pada Tanggal 24 Juni 2015. masyarakat dan kode etik Advokat. Kalangan advokat mengartikan profesi dengan unsur-unsur harus ada ilmu hukum yang diolah di dalamnya;harus ada kebebasan, tidak boleh ada hubungan dinas/hirarkis; dan mengabdi pada kepentingan umum, mencari nafkah tidak menjadi tujuan.

Profesi advokat khususnya dalam pengetahuan mengenai ilmu ekonomi syariahadalah suatu pekerjaan di bidang hukum yang didasari oleh pengetahuan khusus yang harus dipahami secara implisit oleh Advokat. Banyaknya macam akad dan tingkat kerumitan yang tinggi yang menyebabkan ilmu ekonomi syariahmerupakan suatu pengetahuan khusus bagi profesi Advokat. Advokat terlebih dahulu harus memahami tentang ilmu ekonomi syariahagar memiliki keahlian untuk membentuk kecakapan beracara di Pengadilan Agama khususnya sehingga dengan kecakapan khusus tersebut para Advokat dapat memiliki pengetahuan dan pengalaman mengenai pengetahuan khusus ilmu ekonomi syariahuntuk menjalankan pekerjaan profesi Advokat.

HASIL DAN PEMBAHASAN

A. Optimalisasi Peran Advokat dalam Penegakan Hukum Ekonomi Syariah di Pengadilan Agama 
Profesi advokat menggeluti masalah-masalah teknis hukum harus turut berpartisipasi aktif dalam pembangunan hukum nasional. Oleh karena itu, seorang yang berprofesi advokat harus senantiasa mengikuti perkembangan hukum nasional sehingga akhirnya mampu melaksanakan profesinya secara proporsional. Keseimbangan ini baik ditujukan kepada masyarakat yang mampu maupun kepada masyarakat yang tidak mampu memberikan honorarium (fee) atas jasa yang diberikan. Oleh karena itu, advokat selaku profesi penegakan keadilan dapat juga dikatakan sebagai profesi officium nobile.

Sebuah fakta yang tidak terbantahkan menyebutkan bahwa, sebagian besar masyarakat pencari keadilan melalui lembaga pengadilan di negeri ini merasa kecewa, karena sering kali keadilan dan kebenaran itu berpihak kepada penguasa dan kepada masyarakat yang mempunyai kekayaan materiil, dan akhirnya keadilan dan kebenaran itu menjadi sebuah fatamorgana bagi masyarakat pencari keadilan dari kalangan akar rumput/masyarakat ekonomi menegah ke bawah. Masyarakat sudah bosan dan lelah menyaksikan paradoks-paradoks yang terjadi dalam kehidupan hukum di negeri ini. Melalui mata telanjang dan bahkan masyarakat awampun dapat menyaksikan bahwa orang miskin akan sangat kesulitan mencari keadilan diruang pengadilan, sedangkan orang berduit akan begitu mudah mendapatkan keadilan.

Fungsi/peran profesi advokat tidak dapat kita kesampingkan dalam sistem peradilan dan penegakan hukum. Hal ini disebabkan karena profesi advokat sering bersinggungan dengan masyarakat pencari keadilan, polisi, jaksa dan hakim. Oleh karena itu tinjauan atas profesi advokat harus selalu memperhatikan posisinya berhadapan dengan aparat penegak hukum lainnya (Polisi, Jaksa dan Hakim). Namun secara jujur harus diakui pula bahwa profesi advokat juga dapat berperan dalam judicial corruption.

Sebagaimana dikatakan Eman Suparman selaku ketua Komisi Yudisial Republik Indonesia "Peranan pengacara atau Advokat itu sangat dominan untuk mengarahkan terjadinya suap menyuap, karena sering terjadi advokatlah yang mengiming-iming bahkan datang mengetuk pintu rumah para hakim itu untuk menawarkan hasil di persidangan itu disesuaikan dengan jumlah nominal yang ia (Advokat) bawa sebagai konvensasi dari penyelundupan keadilan dan kepastian hukum yang akan diputuskan". ${ }^{11}$

11 Erman Suparman, Disampaikan dalam acara peluncuran buku, Suparman Marzuki, 
Profesi Advokat adalah profesi yang bebas (free profession; vrij beroep), yang tidak tunduk pada hirarki jabatan dan tidak tunduk pada perintah atasan dan hanya menerima perintah atau order atau kuasa dari klient berdasarkan perjanjian yang bebas, baik yang tertulis ataupun tidak tertulis, yang ia (Advokat) tunduk pada Kode Etik Profesi Advokat, tidak tunduk pada kekuasaan publik, seperti Notaris yang merupakan jabatan publik, yang mempunyai kewajiban dan tanggung jawab publik.

Advokat menjalankan tugas profesinya demi tegaknya keadilan berdasarkan hukum untuk kepentingan masyarakat pencari keadilan, Selain dalam proses peradilan, peran Advokat juga terlihat di jalur profesi di luar pengadilan. Kebutuhan jasa hukum Advokat di luar proses peradilan pada saat sekarang semakin meningkat, sejalan dengan semakin berkembangnya kebutuhan hukum masyarakat terutama dalam memasuki kehidupan yang semakin terbuka dalam pergaulan antar bangsa.

Melalui pemberian jasa konsultasi, negosiasi maupun dalam pembuatan kontrak-kontrak dagang, profesi Advokat ikut memberi sumbangan berarti bagi pemberdayaan masyarakat serta pembaharuan hukum nasional khususnya di bidang ekonomi dan perdagangan, termasuk dalam penyelesaian sengketa di luar pengadilan.

Undang-Undang Advokat Nomor 18 tahun 2003 mengatur secara komprehensif berbagai ketentuan penting yang melingkupi profesi Advokat, dengan tetap mempertahankan prinsip

Robohnya Keadilan, di PP Muhammadiyah, Yogyakarta, 12 Maret 2011. kebebasan dan kemandirian Advokat, seperti dalam pengangkatan Advokat, serta ketentuan bagi pengembangan organisasi Advokat yang kuat di masa mendatang. Di samping itu diatur pula berbagai prinsip dalam penyelenggaraan tugas profesi Advokat khususnya dalam peranannya menegakkan keadilan serta terwujudnya prinsip-prinsip negara hukum pada umumnya berkenaan dengan itu perlu diselaraskan standar mutu kemampuan dari Para Advokat itu sendiri.

Berkenan dengan itu standar mutu kemampuan advokat diarahkan untuk meningkatkan dan mengembangkan keterampilan serta keahlian tenaga Advokat guna meningkatkan produktivitas kerja dalam rangka pendayagunaan tenaga advokat secara optimal dan penempatan tenaga advokat pada pekerjaan yang sesuai dengan harkat dan martabat kemanusiaan sebagai bentuk tanggung jawab pemerintah dan masyarakat dalam upaya perluasan kesempatan kerja yang sesuai dengan nilai-nilai Pancasila diarahkan untuk menumbuh kembangkan hubungan yang harmonis, dinamis, dan berkeadilan antar para pelaku dan pengguna jasa hukum advokat.

Lembaga Sertifikasi Profesi Advokat tersebut sangat diperlukan sebagai lembaga yang mempunyai otoritas dan menjadi rujukan dalam penyelenggaraan sertifikasi profesi Advokat secara nasional dan internasional. Dengan demikian, maka akan dapat dibangun suatu sistem sertifikasi Profesi Advokat nasional dan internasional yang diakui oleh semua pihak.

Banyaknya perkara yang timbul akibat situasi tersebut disatu sisi 
memberikan banyak pekerjaan bagi para ahli hukum, salah satunya yang bergerak sebagai Pengacara litigasi. Namun untuk menjadi Pengacara yang tangguh dalam bidang hukum ekonomi syariah diperlukan pengalaman dan keahlian diantaranya adalah dalam membuat gugatan atau menganalisa suatu gugatan ekonomi syariah yang kemudian akan dituangkan dalam membuat suatu Gugatan atau Jawaban. Kadangkala walaupun pokok perkaranya benar namun bila cara membuat gugatannya tidak tepat atau keliru, maka hal itu akan membuat gugatan menjadi kandas ditengah jalan.

Demikian pula dalam kasus ekonomi syariah yang rumit bila tidak dapat memberikan analisa hukum yang tepat atau keliru sehingga dalam membuat Gugatan atau Jawabannya tidak sempurna atau keliru maka hal ini tentunya merugikan kepentingan klien. Untuk itu diperlukan pemantapan keahlian yang harus dimiliki sebelum terjun di bidang Hukum Ekonomi Syariah di Pengadilan Agama.

$$
\text { Untuk mengatasi hal tersebut }
$$
maka diperlukan pendalaman pemahaman terhadap masalah-masalah dasar yang akan sering dijumpai dalam melakukan praktek beracara perdata di Pengadilan Agama. Pemahaman mengenai bagaimana bila akan beracara (perkara ekonomi syariah) di Pengadilan Agama. Pemahaman yang benar akan dapat memberikan jalan keluar atau "problem solving" atas masalah yang diserahkan oleh klien untuk dicarikan jalan keluarnya tersebut. Kadangkala Pengacara ekonomi syariah dapat berperan sebagai Kuasa Tergugat yang harus mampu mengaplikasikan pengetahuan hukum perdatanya baik dari aspek acaranya (formil) maupun dari aspek hukum materiilnya. Hal ini sangat penting untuk diperhatikan karena kesempurnaan dalam membuat suatu Jawaban dapat menggagalkan suatu gugatan dari lawannya. Karenanya tidak ada salahnya kita untuk mempelajari kembali masalah-masalah ini sebagai suatu "refreshing" semasa kuliah dulu sekaligus untuk dapat dijadikan sebagai salah satu pegangan dalam menerapkan ilmunya dalam praktek khususnya dalam Praktek Hukum Perdata khususnya hukum ekonomi syariah.

B. Faktor-Faktor yang Mempengaruhi Rendahnya Peran Advokat dalam Penegakan Hukum Ekonomi Syariah di Pengadilan Agama dalam Wilayah Pengadilan Tinggi Agama Surabaya

Advokat adalah setiap orang yang berprofesi memberi jasa hukum dan bertugas menyelesaikan persoalan hukum kliennya baik secara litigasi maupun nonlitigasi, dan sejak dulu keberadaan advokat selalu ada semacam ambivalensi. ${ }^{84}$ Dalam bahasanya Frans Hendra Winata, tugas advokat adalah mengabdikan dirinya pada masyarakat sehingga dia dituntut untuk selalu turut serta dalam penegakan Hak Asasi Manusia, dan dalam menjalankan profesinya ia bebas untuk membela siapapun, tidak terikat pada perintah (order) klien dan tidak pandang bulu siapa lawan kliennya, apakah dia dari golongan kuat, penguasa, pejabat bahkan rakyat miskin sekalipun. ${ }^{85}$

84 Teguh Adminto, Peran Advokat Dalam Penegakan Hukum Mengenai Implementasi Penanganan Kasus Pro-Bono (Prodeo), http://tittoarema.blogspot.com, Diakses pada Tanggal 7 Desember 2005.

${ }^{85}$ Frans Hendra Winata, Advokat Indonesia, Citra, Idealisme dan Kepribadian, Sinar Harapan, Jakarta, 1995, hlm. 14. 
Salah satu hal yang menarik perhatian adalah peran advokat bukan hanya sebagai spesialisasi dalam penyelesaian pertentangan antara para pencari keadilan, tapi juga sebagai spesialisasi dalam hubungan antara pencari keadilan dan lembaga peradilan. Tanpa ada Advokat yang mengisi fungsi itu secara profesional, masyarakat akan sulit untuk mendapatkan keinginannya untuk memperoleh keadilan. Fungsi Advokat di Pengadilan Agama bukan hanya untuk menjembatani antara kepentingannya dan penegakan hukum di Pengadilan Agama. Fungsi Advokat juga untuk mewakili kepentingan kliennya jika bertentangan dengan orang lain. Berikut adalah faktor-faktor yang mempengaruhi rendahnya peran Advokat dalam penegakan hukum ekonomi syariah di Pengadilan Agama dalam wilayah Pengadilan Tinggi Agama Surabaya.

\section{Rendahnya Pemahaman Advokat tentang Penerapan Hukum Ekonomi Syariah di Pengadilan Agama}

Rendahnya pemahaman Advokat tentang penerapan hukum ekonomi syariah di Pengadilan Agama dapat menyebabkan tidak terakomodirnya keinginan para pencari keadilan untuk mendapatkan hak-haknya. Seharusnya para Advokat dapat memahami dengan detail dan pemahaman yang utuh tentang ilmu ekonomi syariah yang diterapkan di Pengadilan Agama. Hal inilah yang tentunya harus mendapat perhatian khusus dari pemerintah sebagai pemangku kebijakan dan organisasi Advokat sebagai pelaksana kebijakan yang memiliki tanggung jawab untuk memberikan pembinaan. Jika hal ini dapat teratasi tentunya disamping menguntungkan untuk Advokat itu sendiri dalam penanganan perkara ekonomi syariah di Pengadilan Agama tentunya para klien sendiri akan terpenuhi kepentingannya untuk mendapatkan hak yang semestinya dan sesuai dengan ketentuan yang berlaku.

\section{KESIMPULAN}

Berikut adalah kesimpulan yang diperoleh dalam penulisan ini, yaitu.

1. Peran advokat dalam proses penegakan hukum ekonomisyariah di Pengadilan Agama dalam wilayah Pengadilan Tinggi Agama Surabaya saat ini belum optimal. Hal ini dibuktikan dengan masih banyaknya perkara ekonomisyariah yang dalam penangananya terdapat kesalahan pada awalnya misalnya dalam pembuatan gugatan/permohonan sehingga dalam putusan hakim perkara tersebut di NO (Niet Ontvankelijke Verklaard) atau ditolak. Padahal masyarakat pencari keadilan mendambakan hak-haknya terpenuhi (mencapai kebenaran dan keadilan). Peran Advokat dapat optimal apabila mengerti dan memahami pokok perkara yang akan dibelanya, kualitas Advokat yang optimal dengan adanya sertifikasi pengetahuan khusus seperti ilmu ekonomisyariah dan Advokat dapat mengakomodir kepentingan hukum kliennya dengan karakteristik tingkat keilmuan yang dimiliki. Faktorfaktor yang mempengaruhi rendahnya peran advokat dalam penegakan hukum ekonomisyariah 
di Pengadilan Agama dalam

Wilayah Pengadilan Tinggi Agama

Surabaya adalahrendahnya

pemahaman Advokat tentang

penerapan hukum

ekonomisyariahdi Pengadilan

Agama;

2. Diperlukan suatu model pembekalan yang tepat untuk menguatkan kualitas profesionalisme para calon Advokat. Model pembelajaran seperti pelatihan khusus dan magang harusnya digabungkan menjadi satu kesatuan. Antara teori dan praktek tentunya harus bersinergi dan menjadi sangat penting untuk membentuk pemahaman dan pengetahuan hukum yang salah satunya adalah hukum ekonomisyariah oleh Advokat.

\section{Saran}

Berikut adalah saran yang dijadikan rekomendasi dalam penulisan ini, yaitu.

1. Berkenaan dengan belum optimalnya peran advokat dalam proses penegakan hukum ekonomisyariah di Pengadilan Agama dalam wilayah Pengadilan Tinggi Agama Surabaya saat ini diperlukan standar mutu kemampuan advokat yang diarahkan untuk meningkatkan dan mengembangkan keterampilan serta keahlian tenaga Advokat guna meningkatkan produktivitas kerja dalam rangka pendayagunaan tenaga advokat secara optimal dan penempatan tenaga advokat pada pekerjaan yang sesuai dengan harkat dan martabat kemanusiaan sebagai bentuk tanggung jawab pemerintah dan masyarakat dalam upaya perluasan kesempatan kerja yang sesuai dengan nilai-nilai Pancasila diarahkan untuk menumbuh kembangkan hubungan yang harmonis, dinamis, dan berkeadilan antar para pelaku dan pengguna jasa hukum advokat;

2. Dalam menangani kasus ekonomisyariah yang rumit bila tidak dapat memberikan analisa hukum yang tepat atau keliru sehingga dalam membuat Gugatan atau Jawabannya tidak sempurna atau keliru maka hal ini tentunya merugikan kepentingan klien. Untuk itu diperlukan pemantapan keahlian yang harus dimiliki sebelum terjun di bidang Hukum EkonomiSyariah di Pengadilan Agama. Diperlukan pendalaman pemahaman terhadap masalahmasalah dasar yang akan sering dijumpai dalam melakukan praktek beracara perdata di Pengadilan Agama. Pemahaman mengenai bagaimana bila akan beracara (perdata ekonomisyariah) di Pengadilan Agama dalam kaitannya dengan gugatan ekonomisyariah;

3. Diperlukan standarisasi kurikulum pendidikan khusus profesi advokat tentang pemahaman dan pengetahuan hukum ekonomisyariah oleh advokat yaitu dengan (a) peningkatan mutu pendidikan advokat; peningkatan profesionalisme Advokat di Pengadilan Agama; dan (c) diperlukan pusat pendidikan profesi advokat terpadu. 


\section{DAFTAR PUSTAKA}

Ali, Zainudin, Metode Penelitian Hukum, Sinar Grafika, Jakarta, 2009.

Abu Abdillah Muhammad Ibn Ismail Ibn Al-Mugirah Ibn Bardizbah AlBukhari, Shahih Al-Bukhori, Juz 4, Dar Al-Fikr, Beirut Libanon, 1410 $\mathrm{H} / 1990 \mathrm{M}$.

Al-Jauziyah, Ibnu Qayyim, Hukum Acara Peradilan Islam, Pustaka Pelajar, 2006.

Andreae, Fockema, Kamus Istilah Hukum, Terjemahan Saleh Adiwinata, Et, Al, Bina Cipta, Bandung, 1983.

Arif, Saefudin, Praktik Pembagian Harta Peninggalan Berdasarkan Hukum Waris Islam, Darunnajah Publishing, Jakarta, 2007.

Arto,

Murti,

PraktekPerkaraPerdatapadaPenga dilan Agama, PustakaPelajar, Yogyakarta, 1978.

Ash-Shabuni, Muhammad Ali, Diterjemahkanoleh : $\quad$ A.M. Basamalah PembagianWarisMenurut Islam, GemaInsani Press, Jakarta, 1995.

Asy-Syaukani, Muhammad bin Ali, Nailul Al-Author, Juz 6, Cet.1, Darul Hadis, Mesir, 1993 M/1413 H

Coulson, Noel J., Conflicts and Tensions in Islamic Jurisprudence, The University of Chicago Press, Chicago and London, 1969.

Darji Darmodiharjo dan Shidarta, PokokPokok Filsafat Hukum; Apa dan Bagaimana Filsafat Hukum Indonesia, PT. Gramedia Pustaka Utama, Jakarta, 1995.
Fyzet, A.A., The Fatamid Law of Inheritance, HukumWarisFatimiyah, Universityoh Malaya Law Review I, 1965.

Fuady, Munir, Dinamika Teori Hukum, Ghalia Indonesia, Bogor, 2007.

Harahap, Yahya, Beberapa Masalah Hukum Acara pada Peradilan Agama, Yayasan Al-Hikmah, Jakarta, 1993.

, Kedudukan Kewenangan dan Acara Peradilan Agama, Undang-Undang Nomor 7 Tahun 1989, Sinar Grafika, Jakarta, 2009.

Hasan, Hasbi, Kompetensi Peradilan Agama dalam Penyelesaian Sengketa Ekonomi Syariah, Gramata Publishing, Jakarta, 2010.

Hazairin, Hukum dan Kewarisan Bilateral menurut Qur'an dan Haddits, PT. Tirta Mas Indonesia, Jakarta, 1990.

H.R. Otje Salman dan Anton F Susanto, Teori Hukum, Mengingat, Mengumpulkan dan Membuka Kembali, PT. Refika Aditama, Bandung, 2009.

HS., Salim, Perkembangan Teori dalam Ilmu Hukum, Rajawali Press, Jakarta, 2010.

Idris Djakfar dan Taufik Yahya, Kompilasi Hukum Kewarisan Islam, PT. Dunia Pustaka Jaya, Jakarta, 1995.

Kadafi, Binziad, Advokat indonesia Mencari Legitimasi, Cet. Pertama, Pusat Studi Hukum dan Kebijakan Indonesia, Jakarta, 2001.

Katsir, Ibnu, Tafsir Ibnu Katsir (Terjemah), Diterjemahkan oleh Abul Fida Ismail, Sinar Baru Al-Gensindo, Bandung, 2000. 
Kelsen, Hans. General Theory of Law and State.translated by: Anders Wedberg. Russell and Russell, New York, 1961.

Khadduri, Majid, War and Peace in the Law of Islam. The Lawbook Exchage LTD., New Jersey, 2006.

Khalaf, Abdul Wahab, Ilmu Ushul Al-Fiqh, Dar Al- Fikr, Beirut, 1978.

J. Van Kan dan J. H. Beekhuis, Pengantar Ilmu Hukum, PT. Pembangunan Ghalia Indonesia, Jakarta, 1982.

Lev, Daniel S., Mahkamah Agung dan Hukum Waris Adat di Indonesia, PT. Intermasa, Jakarta, 1980.

Levy, Eun, The Social Structure of Islam, University Press, Cambridge, 1962.

Lubis, Suhrawardi K., EtikaProfesiHukum, SinarGrafika, Jakarta, 2002.

Lubis, M. Solly, Filsafat Hukum dan Penelitian, Mandar Maju, Bandung, 1994.

Lubis, Sulaikan, Hukum Acara Perdata Peradilan Agama di Indonesia, Kencana, Jakarta, 2005.

Lubis, T. Mulya, Bantuan Hukum dan Kemiskinan Struktural, Cet. Pertama, LP3 ES, Jakarta, 1986.

Mahkamah Agung RI., Buku II : Pedoman pelaksanaan Tugas dan Administrasi Pengadilan, Cet ke 3, Jakarta, 1993.

, Kumpulan Surat Edaran MA.RI. Tentang Surat Kuasa dan Penasehat Hukum, Jakarta, 1991.
MD., M. Mahfud, Perdebatan Hukum Tata Negara, Pustaka LP3ES, Jakarta, 2007.

Mertokusumo, Sudikno, Hukum Acara Perdata Indonesia, Liberty, Yogyakarta, 1998.

Mertokusumo, Sudikno, Sejarah Peradilan dan Perundang-undangannya di Indonesia Sejak 1942, Cetakan Pertama, Universitas Atma Jaya, Yogyakarta, 2011.

Moleong, Lexy, Metodologi Penelitian Kualitatif, CV. Karya Remaja, Bandung, 2007.

Munawwir, Ahmad Warson, Kamus AlMunawwir, Pustaka Progressif, Surabaya, 1997.

Muthahhari, Murtadha, Keadilan Ilahi : Azas Pandangan Dunia Islam, Mizan, Bandung, 1995.

Nagel, Thomas, The Problem of Global Justice, Philosophy and Public Affairs 33, 2005.

Nasution, Adnan Buyung, Bantuan Hukum di Indonesia, Cet. Ketiga, LP3 ES, Jakarta, 1988.

Nasution, S., Metode research, Jemur, Bandung, 1982.

Prodjodikoro, Wirjono, Hukum Waris di Indonesia, Sumur, Bandung, 1976.

Quthb, Sayyid, Keadilan Sosial dalam Islam, Pustaka, Bandung, 1994.

Rahardjo, Satjipto, Masalah Penegakan Hukum (Suatu Tinjauan Sosiologis), Sinar Baru, Bandung, 1983. 
Rasjid, Roihan A., Hukum Acara Peradilan Agama, Rajawali Pers, Jakarta, 1991.

Rawls, John, A Theory of Justice, Revised Edition, OUP, Oxford, 1999.

Rofik, Ahmad, Fiqh Mawaris, PT. Raja Grafindo Persada, Jakarta, 1998.

Rosen, Lawrence, The Anthropology of Justice : Law as Culture in Islamic Society, Cambridge University Press, New York, 1989.

Salim, Ibrahim, Kedudukan dan Kekuasaan Peradilan Agama, Fakultas Syari'ah IAIN Walisongo, Semarang, 2004.

Sidharta, B. Arief, Meuwissen tentang Pengembangan Hukum, Ilmu Hukum, Teori Hukum dan Filsafat Hukum, PT. Refika Aditama, Bandung, 2009.

Soekanto, Soerjono, Faktor-Faktor yang Mempengaruhi Penegakan Hukum, PT. Raja Grafindo Persada, Jakarta, 2004.

, Pengantar Penelitian Hukum, UI Press, Jakarta, 1984.

, Penegakan Hukum dan Kesadaran Hukum, Naskah Lengkap

Disampaikan pada Seminar Hukum Nasional ke IV, Jakarta, 1979.

, Refleksi Tentang Hukum, PT. Citra Aditya Bakti, Bandung, 2011.

Subekti, R., Kitab Undang-Undang Hukum Perdata, PT. Pradnya Paramita, Jakarta, 1997.

Sumitro, Ronny Hanitijo, Metodologi Penelitian Hukum dan Juru Metri, Ghalia Indonesia, Jakarta, 1994.
Supriyatni, Renny B., Pengantar Hukum Islam, Widya Padjajaran, Bandung, 2011.

Susilawati, Orba, Suatu Tinjauan terhadap Peranan Penasehat Hukum di Pengadilan Agama menurut Hukum Islam, IAIN Imam Bonjol, Bukittinggi, 1992.

Sutiyoso, Bambang, Reformasi Keadilan dan Penegakan Hukum di Indonesia, UII Press, Yogyakarta, 2010.

Tim Penyusun Kamus Pusat Bahasa, Kamus Besar Bahasa Indonesia, Edisi 3, Balai Pustaka, Jakarta, 2001.

Thalib, Sajuti, HukumKewarisan Islam di Indonesia, PT. Bina Aksara, Jakarta, 1981.

Wignyosoebroto, Soetandyo, Masalah Metodologik dalam Penelitian Hukum Sehubungan dengan Masalah Keragaman Pendekatan Konseptualnya, Fakultas Hukum UNDIP, Semarang, 1999.

Winarta, Frans Hendra, Advokat Indonesia, Citra, Idealisme dan Kepribadian, Sinar Harapan, Jakarta,1995.

, Bantuan Hukum Suatu Hak Asasi Manusia Bukan Belas Kasihan, PT. Elex Media Komputindo, Jakarta, 2000.

Yunus, Mahmud, Hukum Warisan Dalam Islam, PT. Hidakarya Agung, Jakarta, 1989. 